\title{
Laparoscopy and anatomic and /or functional defects of pelvic floor
}

\author{
S Palomba", R Oppedisano, C Materazzo, R Venturella, A Falbo, F Zullo \\ From de Senectute: Age and Health Forum \\ Catanzaro, Italy. 5-7 December 2009
}

Ideally each correction of pelvic floor dysfunction may be performed through laparoscopy, even if, in the clinical practice, laparoscopy is an elective route only for few procedures.

Laparoscopy has been largely used for urinary incontinence treatment. After initial experiences performed with simplified techniques, due to high failure rate, it has been abandoned. On the contrary, new evidencebased data have showed that laparoscopy efficacy is similar to laparotomy if performed with the same surgical technique, consisting in at least two sutures for each side $[1,2]$.

However laparoscopic colposuspension for stress incontinence has the same limits and complications as laparotomic. In particular, high rates of posterior defects have been detected, due to non-fisiological widening of posterior pelvic spaces, so a cul-de-sac obliterative technique should be always associated.

Laparoscopy is reaching an important role in apical defects, both for the prolapse of vaginal vault and uterus, both pure and complex. Surely surgical times of laparoscopy are statistically and clinically much longer than for laparotomy, requiring an operative experience not pertaining to the common laparoscopist. Laparoscopic correction advantages are well known, especially for young patients in a fertile age wanting to keep their genital sphere and reproductive potential. In case of patients with a uterine prolapse not wanting to retain uterus, subtotal hysterectomy is commonly employed. It simplifies the technique, colposuspension in fact is performed anchoring cervical core, and is potentially associated with reduced complication rate, not including vaginal opening. In cases of pure apical defect essential steps are the $2-3 \mathrm{~cm}$ exposure of anterior and posterior fascia of the vault and its anchorage to sacrum. On the

Department of Obstetrics and Gynecology, University "Magna Graecia" of Catanzaro, Catanzaro 88100, Italy contrary, when apical defect is part of a complex dysfunction, exposure and protection with mesh of anterior vaginal wall to bladder pillars and of posterior one to the ano-rectal junction are necessary, and an anti-incontinence procedure and an obliterative procedure should be always associated.

\section{Conclusions}

Laparoscopy is a feasible approach for pelvic floor dysfunction correction. Further data are necessary to obtain definitive conclusions.

Published: 19 May 2010

\section{References}

1. Carey MP, Goh JT, Rosamilia A, Cornish A, Gordon I, Hawthorne G, Maher CF, Dwyer PL, Moran P, Gilmour DT: Laparoscopic versus open Burch colposuspension: a randomised controlled trial. BJOG 2006, 113:999-1006.

2. Kitchener HC, Dunn G, Lawton V, Reid F, Nelson L, Smith AR: COLPO Study Group, Laparoscopic versus open colposuspension-results of a prospective randomised controlled trial. BJOG 2006, 113:1007-1013.

doi:10.1186/1471-2318-10-S1-L13

Cite this article as: Palomba et al:: Laparoscopy and anatomic and /or functional defects of pelvic floor. BMC Geriatrics 2010 10(Suppl 1):L13.

Submit your next manuscript to BioMed Central and take full advantage of:

- Convenient online submission

- Thorough peer review

- No space constraints or color figure charges

- Immediate publication on acceptance

- Inclusion in PubMed, CAS, Scopus and Google Scholar

- Research which is freely available for redistribution 